\title{
The System of Lithuanian Business Enterprises and Macroeconomic Efficiency of Its Elements
}

\author{
Gediminas Davulis \\ Vilniaus kolegija/University of Applied Sciences, Vilnius, Lithuania
}

\begin{abstract}
The article deals with the system of Lithuanian enterprises, its classification according to the legal forms and their sizes. Eleven legal forms of business enterprises have been legalized by the corresponding laws of the Republic of Lithuania. According to the Lithuanian law, enterprises are classified by their size into large, middle-sized, small, and very small enterprises. The characteristics of each kind of Lithuanian business are discussed. The macroeconomic criterion of efficiency for assessment of activities of kinds of enterprises is presented. The proposed criterion of efficiency includes social aspects expressing a contribution of individual kinds of enterprises to the country's GDP. The investigation of how the extreme conditions, i.e., global crisis, impact on macroeconomic efficiency of enterprises kinds was performed using the basis of statistical date. The result of calculations shows that situation in the sphere of macroeconomic efficiency differs insignificantly before and after economic crisis. The analysis of macroeconomic efficiency showed that most effective are large enterprises because their contribution to the GDP of country is bigger than other enterprises. According to legal form, the public limited liability companies are most effective because usually they are large enterprises.
\end{abstract}

Keywords: structure of business system, classification of enterprises, macroeconomic efficiency

\section{Introduction}

A number of authors deal with various aspects of business system and its subject activities, i.e., Banys, Rudminaitis, and Grybenas (2006); Ciochina, Manole, and Decuseara (2008); Dikčius, Rudzkis, and Dulskis (2007); Griffiths and Wall (2008); Gunasekaran, Rai, and Griffin (2013); Misiūnas (2008); Žutautienè (2007). Profit criterion is used usually for evaluation for assessment of efficiency of business enterprises. In this article is proposed the novelty - to use a new criterion efficiency for various kinds of enterprises, which reflects macroeconomics aspects of activity of kinds of enterprises. The proposed criterion of efficiency includes social aspects which express a contribution of individual kinds of enterprises to the country's GDP. Research object of this article is to analyze the structure of the system of business enterprises in Lithuania, to define macroeconomic efficiency of business enterprises. On the basis of statistical data the macroeconomic efficiency of individual kinds of business enterprises is calculated.

\section{Classification of Business Enterprises in Lithuania}

There are three legal main forms of business enterprises_individual enterprises, partnerships, and joint stock companies. However, in concrete countries is legalized a much wider circle of forms of companies.

Gediminas Davulis, professor, Ph.D., International Business Department, Vilniaus kolegija/University of Applied Sciences. 
According to the existing legislation, in Lithuania a natural person can engage in business by purchasing a business license thus validating individual activities or by establishing an enterprise. The business enterprises in Lithuania are classified according their legal forms and their sizes. The following basic forms of enterprises are legalized by the corresponding laws of the Republic of Lithuania:

(1) Individual (personal) enterprise;

(2) General partnership;

(3) Limited partnership;

(4) Small partnership;

(5) Public limited liability company, private limited liability company, and investment company;

(6) State-owned enterprise;

(7) Municipal enterprise;

(8) Agricultural company;

(9) Co-operative society;

(10) European company;

(11) European co-operative society.

The individual enterprise is owned by one natural person or several natural persons by the right of joint ownership. The organizations that have a legal person's rights and are not engaged in production, may also own an individual enterprise. Individual enterprise is unlimited civil liability private legal person which assets not separated from the owner's private property. The owner is liable for the obligations of the enterprise to the extent of all his property.

General partnership is an unlimited civil liability private legal person established by several natural or legal persons by combining their property under a plan of co-ownership on the basis of a partnership agreement. The general partners are jointly and severally liable for the obligations of the general partnership to the extent of all their individual property. The general partnership is not liable for the obligations of its partners, when such obligations are incurred through the activity not related to the activities of the general partnership.

The limited partnership consists of the general and limited partners acting under the single name of the firm who own the property of the enterprise by the right of joint ownership. The limited partnership is a limited civil liability private legal person but its property is not separated from the property of the general partners. The general members of the limited partnership are jointly and severally liable for the obligations of the limited partnership to the extent of all their property, whereas limited partners are liable only for the share of their property transferred under the partnership agreement of the limited partnership. The limited partnership is not liable for the obligations of its partners, when such obligations are incurred by the activity not related to the activity of the partnership. The limited partnership must have at least one general and at least one limited partner. Natural or legal persons may become members of limited partnerships.

The small partnership is an unlimited civil liability private legal person, which all members are natural persons whose number must not exceed 10 persons. The members of small partnership must make a contribution to the capital of the partnership in the manner prescribed by the small partnership law.

The public company and private company is limited civil liability private legal person, whose capital is divided into shares. The shareholders are the members of a public or a private company who have become members upon acquiring shares of the above companies in the manner prescribed by law. The shareholders may be the natural or legal persons or the state, represented by a corresponding state institution. The 
shareholders have the ownership rights of shares. The shares of private company are in the sphere of closed circulation.

The state-owned (municipal) enterprise is the limited civil liability public legal person, all the assets of which are owned by the Republic of Lithuania or by the municipality. The state (municipality) is not liable for the obligations of the enterprise and vice versa. State-owned and municipal enterprises manage, use, and dispose the enterprise's assets held in trust. State capital in state-owned and municipal enterprises is represented by the employees of corresponding institutions in the manner prescribed by Government of Republic of Lithuania.

Agricultural company is an enterprise formed by the natural persons joining their property into jointly owned property for production and commercial activities in agriculture. Agricultural company must have at least two members. There are no limits for the maximum number of members. Agricultural company is the limited civil liability private legal person. The Lithuanian citizens or Lithuanian citizens jointly with citizens of foreign countries may become the founders of a company.

A co-operative society is an economical entity with changeable composition and capital established on a voluntary basis by a group of natural persons or natural and legal persons for the purpose of satisfying business, economic and social needs of its members and functioning on their initiative and at their risk. A co-operative society is an economic entity of limited civil liability private legal person liable for its obligations to the extent of its property and not liable for the obligations of its members, which are not related to the activities of the co-operative society. A co-operative society must have not less than three natural or natural and legal persons. Not less than five persons, who are citizens of the Republic of Lithuania and are 18 years old and over, or citizens and legal persons registered in Lithuania may be the founders of a co-operative society.

The European company is a limited civil liability private legal person company, whose authorized capital is divided into parts-shares. The title of European companies must bear the sign "SE". The European companies' capital (equity) has to meet the requirements set by the European Union Council; it cannot be less than 120,000 EUR. The company's seat must be in some European Union country, in which there is its headquarters. The seat can be moved to other European Union Member State. European companies, whose headquarters are in the Republic of Lithuania, are subordinate to the law of the Republic of Lithuania that regulates public limited companies to the extent permitted by the European Union Council Regulations, the law of the Republic of Lithuania on the European Companies, and other legal acts governing the companies. European companies pay taxes according to the laws of the state where they have a registered office. In accordance with the order established by Government, Lithuanian Ministry of Justice has the right to oppose the relocation of the seat of European company to another country, if it violates the public interest. Disputes as to the relocation of the headquarters to another country are settled by the judicial order.

European cooperative company is a limited civil liability private legal person company. Its office and headquarter location must be the same. The residence may be relocated to other European Union country. The Republic of Lithuania applies its laws on cooperatives and public limited companies to European cooperatives companies, the residence of which is in the Republic of Lithuania, to the extent permitted by the European Union Council Regulations, the Lithuanian laws, and other legal acts. In accordance with the order established by Government the Lithuanian Ministry of Justice has the right to oppose the relocation of a European Cooperative Society office to another country if it violates the public interest. Disputes referring to the relocation of the headquarters to another country are settled by the judicial order. 
According to the Lithuanian law, enterprises can be classified by their size, namely, into large, middle-sized, small, and very small enterprises. Large enterprise is an enterprise, which employs no less than 250 employees. Middle-sized, small, and very small enterprises make up the small and average business base in Lithuania and are defined as follows. Middle-sized enterprise is a company, which employs less than 250 employees, while financial indicators meet at least one of the following requirements: Annual income does not exceed 138 mill Lt (litas), and the value of property, indicated in the balance sheet, does not exceed 93 mill Lt. Small enterprise is a company, which employs less than 50 employees and its annual income and assets in the annual balance sheet should not exceed 24 mill, and 17 mill Lt, respectively. Very small enterprise is a company, where less than 10 employees are working and its annual income and assets in the annual balance sheet does not exceed 7 mill and 5 mill Lt, respectively. These criteria, valid in Lithuania, are coordinated with that presented in the Recommendation 2003/361/EC of the European Commission. According to data of Lithuanian Statistic Department, the biggest share of all numbers of enterprises (more than 95 percent) comprised the small and very small enterprises. Rest forms of enterprises, i.e., middle-sized and large enterprises comprised insignificant share of all enterprises (see Figure 1).

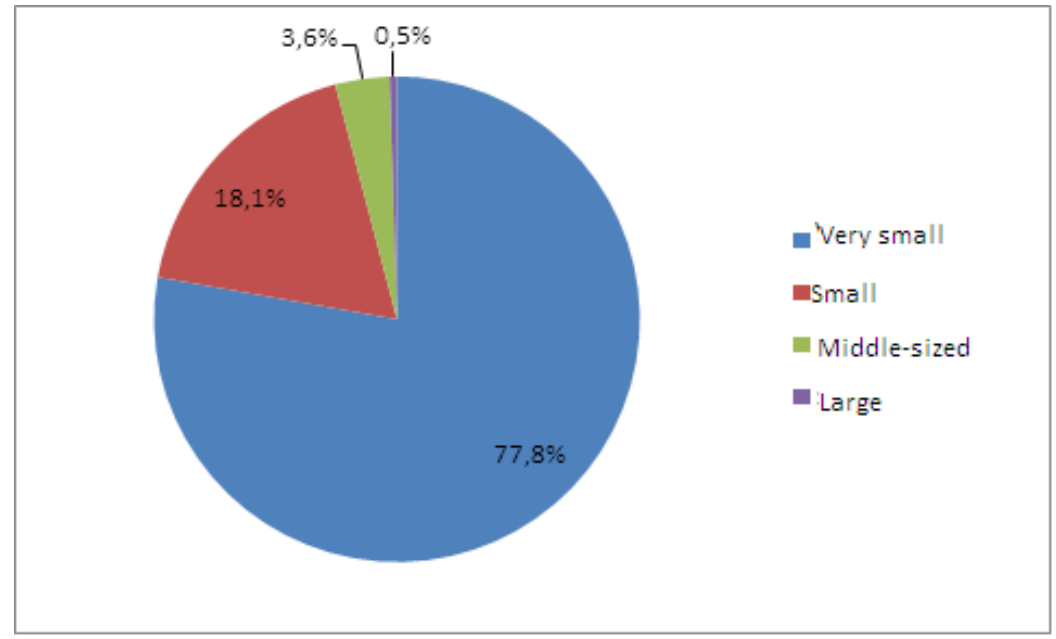

Figure 1. The structure of Lithuanian business enterprises system according to their size in 2012.

\section{The Assessment of Macroeconomic Efficiency of Kinds of Enterprises}

For assessment of macroeconomic efficiency of individual kinds of enterprises can be used the coefficient of macroeconomic efficiency. This coefficient is calculated as ratio between contribution to countries GDP of concrete kind of enterprises (in percent) and the share of employees (in percent) that works in this kind of enterprises. The coefficient of macroeconomic efficiency for very small, small, middle-sized, and large enterprises we will calculate in 2007 and 2010 years, i.e., before and after economic crisis using the data of Lithuanian Statistic Department. The data for calculate the coefficient of macroeconomic efficiency at 2007 year are presented in Figure 2 and Figure 3.

As Figure 2 shows, the most share of employees worked in MS (middle-sized) enterprises, i.e., about 30 percent, the share of employees in the small and VS (very small) enterprises comprised about 44 percent only, though share of number of these enterprises comprised about 95 percent. 


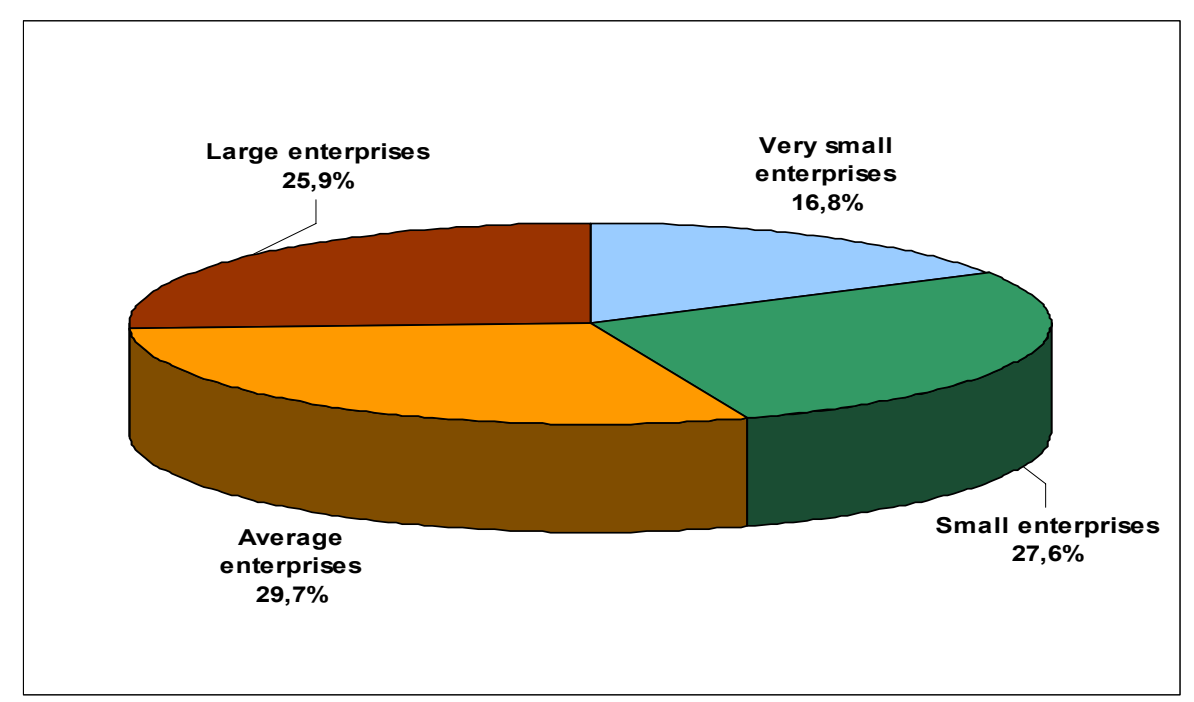

Figure 2. The distribution of employees according to the size of enterprises in 2007.

Thus the Figure 3 shows though most share of employees worked in MS enterprises, however large enterprises gives the more contribution to GDP of country (about 36 percent of GDP). Small and very small enterprises together create approximately the same share of GDP as middle-sized enterprises. The coefficients of macroeconomic efficiency calculated according these data for very small, small, middle-sized, and large enterprises are equal, correspondently, $0.63,0.85,1.01$, and 1.34 . Thus large enterprises are characterized by most productivity. The small and very small enterprises are not very efficiency but these enterprises create the more wide possibilities of choosing and allow us to solve the unemployment problem. The efficiency of large enterprises can be explained by economy of the scale because large enterprises have more abilities to realize the advantages of workers specialization and to use specialized and more productive equipment and technologies. The coefficients of macroeconomic efficiency for 2010 calculated using data of Lithuanian Statistic department for large, middle-sized, small, and very small enterprises are 1.37, 1.03, 0.82, and 0.63. Thus the result of calculations shows that situation in the sphere of macroeconomic efficiency differs insignificantly before and after economic crisis.

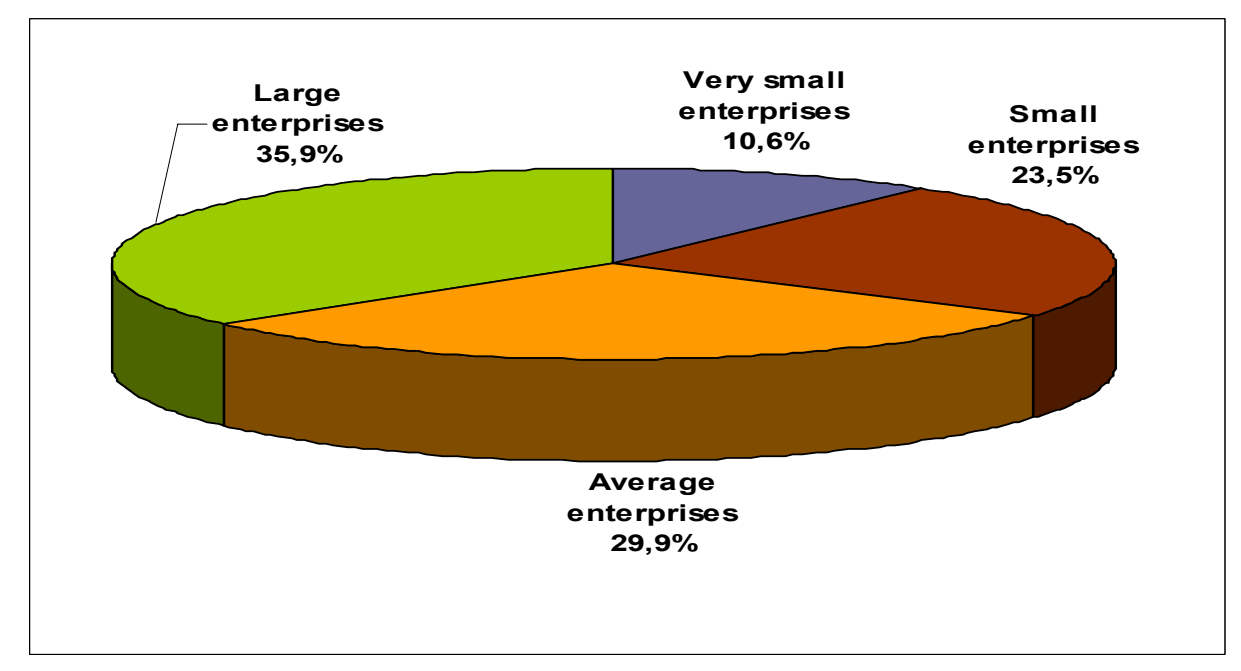

Figure 3. The shares of GDP, created in 2007 according to the size of enterprises (\%). 
Analogously the coefficient of macroeconomic efficiency can be calculated for individual legal forms of enterprises, too. The data of Lithuanian Statistical department at 2007 show that private limited liability companies (PRIVLLC) create the biggest share of GDP of country exceed 70 percent of value of GDP. The public limited liability companies (PUBLLC) created about 20 percent of GDP and personal enterprises (PE) about 6 percent of GDP. Rest legal forms of enterprises create less than 5 percent of GDP. On the other hand the most share of employees worked in PRIVLLC, i.e., about 74 percent, the share of employees in the PUBLLC and PE comprised about 11 percent in each of them only.

The coefficient of macroeconomic efficiency for PUBLLC, PRIVLLC, PE, and others enterprises calculated using Statistic department data for 2007 are 1.73, 0.95, 0.55, and 0.91. The biggest coefficient of macroeconomic efficiency for public limited liability companies shows that enterprises of this legal form are most effective. This result can be explained by the fact that public limited liability companies are usually large enterprises. The result of calculations shows that the coefficients of macroeconomic efficiency at 2010 are similar, i.e., it differs insignificantly before and after economic crisis.

\section{Conclusion}

The analysis of statistical data showed that the economic crisis impacted insignificantly on macroeconomic efficiency of business system of Lithuania. The analysis of macroeconomic efficiency showed that most effective are large enterprises because their contribution to the GDP of country is biggest than other enterprises. According to legal form, the public limited liability companies are most effective because usually they are large enterprises. The efficiency of large enterprises can be explained by the effect of economy of the scale.

\section{References}

Banys, R., Rudminaitis, V., \& Grybenas, V. (2006). Smulkaus ir vidutinio verslo plètros kliūtys Lietuvoje (The obstacles for development of small and middle-sized business). In Socialiniai mokslai: Ekonomika (Social sciences: Economics). Vilnius: Vilniaus universitetas.

Bartkus, E., \& Piktys, R. (2008). Imoniu organizavimas ir rizika: smulkaus verslo organizavimas (The organization and risk of enterprises: The organization of small business). Kaunas: Technologija.

Ciochina I., Manole, D. S., \& Decuseara, R. (2008). The competitive advantages of small and medium enterprises [PDF document]. Retrieved from http://steconomice.uoradea.ro/anale/volume/2008/v4-management-marketing/147.pdf

Dikčius, V., Rudzkis, R., \& Dulskis, D. (2007). Lietuvos mažų ir vidutiniu įmonių būklè ir plètros tendencijos (The state of small and middle-sized enterprises in Lithuania and their development tendencies). Lietuvos ekonomika Europoje ir globalioje erdveje: straipsniu rinkinys, 267-279.

Griffiths, A., \& Wall, S. (2008). Economics for business and management (2nd ed.). Harlow: Pearson Education Limited.

Gunasekaran, A., Rai, B. K., \& Griffin, M. (2013). Resilience and competitiveness of small and medium size enterprises: An empirical research. International Journal of Production Research, 49(18), 5489-5509.

Juozaitienè, L., \& Steponkienè, J. (2008). Verslo ir vadybos ǰvadas (Introduction to business and management). Šiauliai: Šiauliu universiteto leidykla.

Misiūnas, A. (2008). Verslo plètros įtaka šalies ekonomikai: mokslinis tyrimas (The impact of business development on country's economy: Scientific research). Lietuvos statistikos darbai, 47, 27-29.

Žutautienė, J. (2007). Verslo ekonomika (Business economy). Klaipėda: Klaipėdos universiteto leidykla. 